\title{
KOMPOSISI NEMATOSIT KARANG FUNGIA, Cycloseris vaugani DARI TERUMBU KARANG PANTAI MALALAYANG, MANADO
}

\author{
(Nematocyst Composition of the Coral Fungia, Cycloseris vaugani from \\ Malalayang Beach Coral Reef, Manado)
}

\section{Adelin M. Sagrang ${ }^{1}$, Carolus P. Paruntu ${ }^{1 *}$, Billy Th. Wagey ${ }^{1}$, Kakaskasen A. Roeroe ${ }^{1}$, Medy Ompi ${ }^{1}$, Adnan S. Wantasen ${ }^{2}$}

1. Mahasiswa Program Studi IImu Kelautan, FPIK UNSRAT Manado

2. Staf Pengajar Program Studi IImu Kelautan FPIK UNSRAT Manado

3. Staf Pengajar Program Studi Manajemen Sumber Daya Perairan, FPIK UNSRAT, Manado. 95115. Sulawesi Utara. Indonesia

Penulis korespondensi: Carolus P. Paruntu; carolusparuntu@unsrat.ac.id

\begin{abstract}
The purpose of this study was to determine the composition of nematocysts in the body tissue of the coral fungia, $C$. vaugani. The location for the collection of $C$. vaugani colonies was on the coral reefs of the Malalayang coastal area, Manado. This research was carried out in September - December 2020. The observation of nematocysts of $C$. vaugani was carried out using an Olympus CX41 microscope with a magnification of $x 100$ objective lens which connected to a computer monitor equipped with an optical view 7 application at the Fish Health Environment and Toxicology Laboratory, Faculty of Fisheries and Marine Science, UNSRAT. The present results showed that $C$. vaugani had a composition of nematocysts, namely type I microbasic $\mathrm{p}$-mastigophore (MpM-I) of $40.00 \%$, small type II microbasic p-mastigophore (sMpM-II) of $31.11 \%$, small holotrichous isorhizas $(\mathrm{sHI})$ of $24.44 \%$, large type II microbasic $\mathrm{p}$-mastigophore (MpM-II) of $2.22 \%$, and large holotrichous isorhizas $(/ \mathrm{HI})$ of $2.22 \%$. $s \mathrm{MpM}-\mathrm{II}$ is the most dominant nematocyst type of $C$. vaugani and this type of nematocyst is thought to be used by coral for aggression and killing prey or predator if there is disturbance from the surrounding aquatic environment where the coral lives. Further research is recommended to study the types and morphology of nematocyst from various species of coral fungia, including $C$. vaugani to understand the differences in their types and dimension of the nematocyst.
\end{abstract}

Keywords: Composition, Cycloseris vaugani, Fungia, Manado, nematosit

\begin{abstract}
ABSTRAK
Studi ini bertujuan untuk mengetahui komposisi nematosit pada jaringan tubuh karang fungia, $C$. vaugani. Lokasi pengambilan koloni-koloni karang, C. vaugani berada di terumbu karang kawasan pesisir Malalayang, Kota Manado. Penelitian ini dilaksanakan pada September - Desember 2020. Pengamatan nematosit dari C. vaugani dilakukan dengan menggunakan mikroskop Olympus CX41 dengan perbesaran lensa objektif x100 yang dihubungkan dengan monitor komputer dilengkapi dengan aplikasi optica view 7 pada Laboratorium Kesehatan Ikan, Lingkungan dan Toksikologi, Fakultas Perikanan dan IImu Kelautan, UNSRAT. Hasil penelitian menunjukkan bahwa C. vaugani memiliki komposisi tipe-tipe nematosit, yaitu microbasic p-mastigophore tipe I (MpM-I) sebesar $40,00 \%$, small microbasic p-mastigophore tipe II (sMpM-II) 31,11\%, small holotrichous isorhizas ( $\mathrm{sH}$ ) $24,44 \%$, large microbasic p-mastigophore tipe II (MpM-II) 2,22\%, dan large holotrichous isorhiza (IHI) 2,22\%. sMpM-II merupakan tipe nematosit yang paling dominan dan tipe nematosit ini diduga digunakan oleh $C$. vaugani untuk menyerang dan membunuh mangsa yang ada di sekitarnya.
\end{abstract}


Penelitian lebih lanjut disarankan untuk mengkaji tipe dan morfologi nematosit dari berbagai jenis karang fungia, termasuk $C$. vaugani untuk memahami perbedaan tipe dan dimensi nematositnya.

Kata Kunci: Cycloseris vaugani, Fungia, komposisi, Manado, nematosit

\section{PENDAHULUAN}

Ordo Scleractinia adalah salah satu kelompok fauna karang yang tergolong pada filum Cnidaria sebagai fauna utama pembentuk ekosistem terumbu karang. Karang batu (stony coral) dari ordo Scleractinia adalah fauna yang mampu mendeposit kalsium karbonat (CaCO3) sebagai kerangka kapur atau skeleton hewan karang ini (Prasetya, 2003; Suharsono, 2008).

Polip karang terdapat 3 (tiga) lapisan jaringan tubuh, yaitu lapisan ektordermis, mesoglea dan endodermis (Veron, 1986; Suharsono, 2008). Cnidarian adalah sebuah filum yang mempunyai sel penyengat dalam jaringan tubuh ektodermisnya, yang disebut cnidae. Sel cnidae ini dapat melepaskan tangkai dan atau benang beracun dari kapsul dan keluar dari tubuh karang untuk menyerang mangsa atau predator di lingkungan sekitarnya (Paruntu, 2000; Yue, et. al. 2020). Cnidae berada dalam sel cnidocyte, yang terdiri dari sel nematosit, sel ptikosit dan sel spirosit (Mariscal, 1984; Watson dan Wood, 1988). Sel nematosit adalah sel penyengat berfungsi sebagai alat penangkap makanan dan mempertahankan diri. Nematosit adalah sel yang dimilki oleh filum Cnidaria, berada di lapisan tubuh ektodermisnya, dan mengandung zat beracun (Schlesinger, dkk. 2009). Sekitar 30 tipe nematosit (nematosit dan spirosit) dari fauna Cnidaria telah digambarkan oleh beberapa ahli (Mariscal, 1974; 1984; Ostman, 2000).

Paruntu, dkk. (2000) menyatakan bahwa ada perbedaan komposisi tipe nematosit pada setiap fase pertumbuhan karang Pocillopora damicornis, yaitu dari larva, polip-polip atau koloni muda sampai pada koloni-koloni dewasa. Perbedaan komposisi tipe-tipe nematosit telah diamati juga pada $P$. eydouxi, $P$. woodjonesidan $P$. verucosa oleh Paruntu, dkk. (2013) dan disarankan ketiga spesies karang tersebut adalah jenis-jenis karang yang berbeda berdasarkan tipe dan morfologi nematosit. Pada umumnya perbedaan tipe dan morfologi nematosit pada fauna Cnidaria telah disarankan sebagai karakter yang bermanfaat dalam taksonomi ordo-ordo Cnidaria (Lang, 1986; Pires dan Pitombo, 1992, Ostman, 2000; Fautin, 2009).

Karang fungia disebut karang jamur yang tergolong dalam ordo Scleractinia, hidupnya soliter (free-living) dan dapat hidup pada bermacam-macam substrat. Habitat karang fungia dapat juga berada di rataan terumbu karang maupun dasar perairan yang berpasir (Hoeksema, 1989; 2012; Hoeksema, dkk. 2016). Gofredo dan Chadwick-Furman (2000) telah melaporkan tentang kelimpahan dan distribusi dari karang-karang fungia (Scleractinia: Fungiidae) pada terumbu karang di Eilat, Northern Red Sea.

Karang fungia, C. vaugani terlihat berlimpah di kawasan terumbu karang pesisir pantai Malalayang Dua, Kota Manado. Bagaimanapun jenis karang $C$. vaugani sampai saat ini belum pernah diteliti tentang komposisi dan tipe nematositnya sebagai karakteristik dalam taksonomi karang untuk membedakan jenis karang fungia ini dengan jenis lainnya dalam ordo Scleractinia. Studi ini bertujuan untuk mengkaji komposisi dan tipe nematosit pada karang $C$. vaugani. 


\section{METODE PENELITIAN}

\section{Tempat dan Waktu Penelitian}

Titik koordinat lokasi penelitian, yaitu 1027'39.6" Lintang Utara dan 1244ㄱ'30.6" Bujur Timur (Gambar 1). Selanjutnya sampel karang uji ini diteliti di
Labotorium Kesehatan Ikan, Lingkungan dan Toksikologi, Fakultas Perikanan dan Ilmu Kelautan, Universitas Sam Ratulangi. Periode penelitian adalah dari bulan September - Desember 2020.
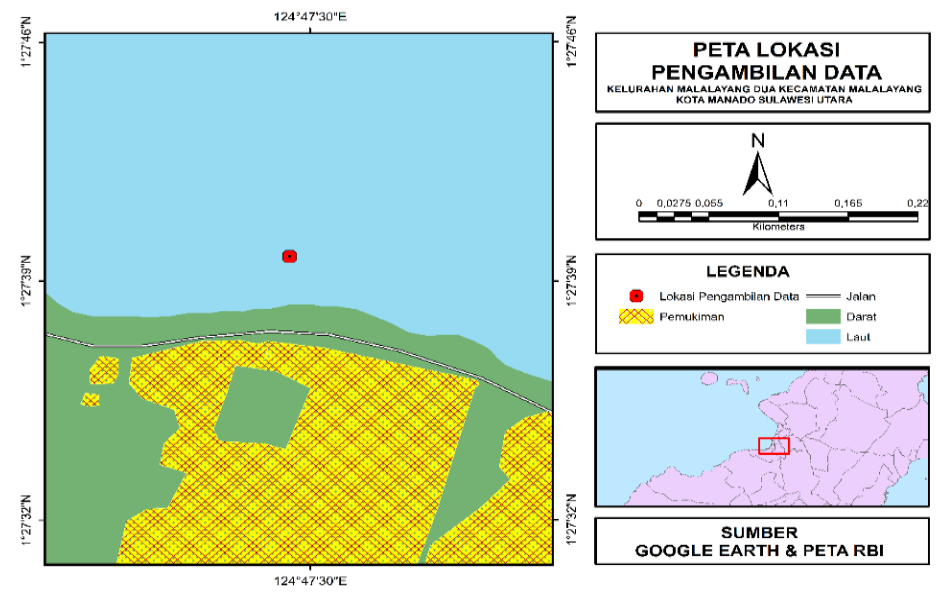

Gambar 1. Peta lokasi pengambilan sampel.

\section{Alat dan Bahan}

Dalam penelitian ini digunakan peralatan dan bahan, yaitu peralatan scuba diving, global positioning system (GPS), mikroskop Olympus CX41, gelas ukur, kamera bawah air, pinset, pipet, pensil, cover glass, slide glass, toples, software optika view 7, air tawar, alkohol $70 \%$, larutan campuran formalin $40 \%$ dan asam asetat $40 \%(1: 1)$, sampel karang uji (C. vaugani).

\section{Teknik Pengumpulan Data}

Teknik pengumpulan data dilakukan di lapangan (laut) dan di laboratorium. Sampel karang uji dikoleksi di lapangan, sedangkan pengukuran data nematosit dilakukan di laboratorium. Khususnya teknik pengumpulan data nematosit karang dilakukan dengan metode observasi di laboratorium mengacu pada Paruntu (1996) dan Paruntu, dkk. (2000), yaitu dengan mengamati sampel karang secara langsung di bawah mikroskop untuk melihat objek penelitian berupa sel nematosit karang dan mencatat serta mendokumentasi segala informasi yang diamati.

\section{a. Pengumpulan data di lapangan}

Sampel karang uji fungia, $C$. vaugani diambil pada kedalaman sekitar 3-7 meter dengan menggunakan alat scuba diving di daerah terumbu karang Pantai Malalayang Dua Kota Manado. Spesies dari karang fungia, $C$. vaugani diambil empat koloni dan diletakkan di dalam ember berisi air laut secukupnya, selanjutnya sampel karang uji dibawa ke Laboratorium Biologi Laut FPIK UNSRAT.

\section{b. Pengumpulan data di laboratorium}

Di Laboratorium Biologi Laut, koloni-koloni karang uji yang masih segar difoto untuk dokumentasi (Gambar 2). Selanjutnya tiga koloni sampel karang uji tersebut disimpan di dalam wadah toples plastik yang berisi alkohol $70 \%$ untuk pengawetan. Disamping itu, satu koloni 
karang uji lainnya direndam dalam larutan pemutih seperti cairan bycline dalam waktu tiga hari untuk mendapatkan kerangka skeleton karang yang putih dan bersih, serta dibuat dokumentasi juga (Gambar 2).
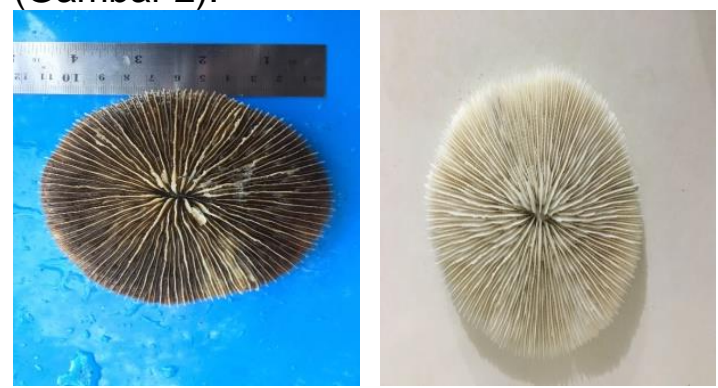

Gambar 2. Sampel karang hidup (kiri) dan skeleton karang (kanan) dari fungia, C. vaugani.

Pengujian nematosit di laboratorium dilakukan dengan tahapantahapan, sebagai berikut:

\section{1). Dekalsifikasi koloni karang}

Sampel karang uji yang disimpan dalam alkohol $70 \%$ diambil dan dilakukan dekalsifikasi dalam larutan kimia, campuran asam asetat $40 \%$ dan formalin $40 \%$ dangan perbandingan $1: 1$ selama periode 3 (tiga) hari. Proses dekalsifikasi ini bertujuan untuk mendapatkan jaringan tubuh karang yang lunak yang digunakan dalam pengamatan sel nematosit.

\section{2). Pengujian nematosit di bawah} mikroskop

Potongan kecil jaringan lunak tubuh karang diambil dengan pinset dan dibilas dengan air tawar dalam cawan petridis sebelum diamati di bawah mikroskop. Sampel potongan kecil jaringan lunak itu diamati di bawah mikroskop Olympus CX41 yang terhubung dengan monitor komputer menggunakan slide glass dan cover glass untuk melihat kandungan tipe-tipe nematosit yang dimilikinya (Gambar 3).

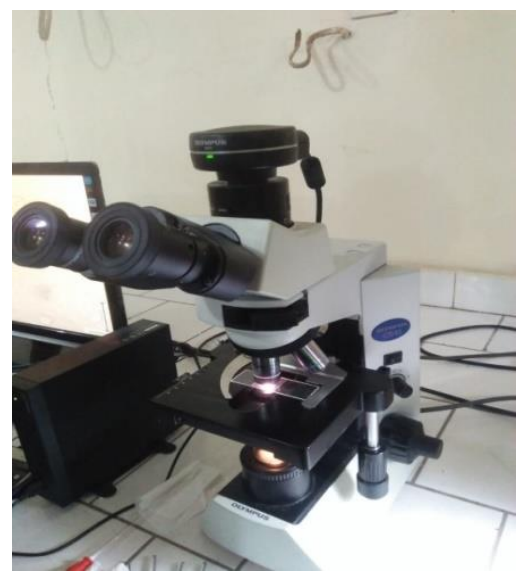

Gambar 3. Proses pengamatan nematosit dengan menggunakan mikroskop Olympus CX41 yang terhubung dengan komputer.

3). Komposisi nematosit

Perhitungan komposisi nematosit adalah jumlah setiap tipe nematosit dari setiap koloni karang uji yang diamati di bawah mikroskop, dihitung paling sedikit 10 nematosit yang terdapat pada 15 area pengamatan yang telah ditetapkan. Pengujian komposisi nematosit dikhususkan pada tipe - tipe nematosit yang dapat diidentifikasi dan dihitung saja. Komposisi nematosit dihitung dalam satuan persen (\%) dan dianalisis dengan menggunakan software excel.

\section{HASIL DAN PEMBAHASAN}

\section{Komposisi Tipe-tipe Nematosit}

Komposisi tipe-tipe nematosit utama dari karang fungia, C. vaugani, yaitu microbasic p-mastigophore tipe I (MpM-I) sebesar 40\%, small microbasic $\mathrm{p}$ mastigophore tipe II (sMpM-II) 31,11\%, small holotrichous isorhizas ( $\mathrm{sHI}$ ) 24,44 $\%$, large microbasic p-mastigophore tipe II (MpM-II) 2,22\%, dan large holotrichous isorhiza (IHI) 2,22\% (Gambar 4 \& 5). Tipe MpM-II dan $\mathrm{HI}$ memiliki ukuran lebih besar dibandingkan dengan sMpM-II dan $s \mathrm{HI}$. Kapsul HI mempunyai benang yang 
berduri tapi tidak memiliki tangkai, sedangkan kapsul MpM memiliki tangkai bentuk huruf " $V$ " dan benang yang berduri (Gambar 4).

$$
\text { Paruntu, dkk. (2000) }
$$

memperlihatkan $P$. damicornis koloni dewasa memiliki nilai komposisi nematosit, MpM-I sekitar $10 \%$, MpM-II 5 $\%$, small $\mathrm{HI} 3 \%$, MbM $45 \%$ dan spirosit $37 \%$ Paruntu dan Souw (2014) menyatakan bahwa nilai komposisi tipe MpM-II sebesar 54,15 \% dan HI 45,85 \% pada $S$. hystrix, kemudian pada $S$. caliendrum memiliki komposisi tipe nematosit MpM-II sebesar 45,28 \% dan $\mathrm{HI}$ 54,72 \%. Gagu, dkk. (2019) memperlihatkan komposisi tipe nematosit MpM-II bernilai 95,56 \% dan $\mathrm{HI}$ 4,44 \% pada $A$. florida, sedangkan pada $A$. divaricata memiliki komposisi MpM-II sebesar $100 \%$.

Perbedaan komposisi tipe nematosit pada beberapa jenis karang di atas yang ditunjukkan baik pada penelitian saat ini maupun penelitian sebelumnya, itu disebabkan karena masing-masing jenis karang mempunyai komposisi nematosit spesifiknya.

Paruntu (1996) menyatakan bahwa tipe microbasic p-mastigophore (MpM) dimanfaatkan oleh karang untuk menyerang cnidaria lain dan mematikan mangsa yang ada di sekitarnya. Studi saat ini memperlihatkan juga kehadiran dari MpM pada fungia, C. vaugani, yang mungkin ini digunakan sebagai alat untuk mempertahankan diri dari pemangsa. Holotrichous isorhiza merupakan tipe nematosit yang dipakai oleh fauna Cnidarian sebagai alat pertahanan dan menyerang mangsa disekitarnya yang dapat merusak jaringan tubuh fauna yang diserang (Den Hartog, 1977). Studi saat ini memperlihatkan juga kehadiran $\mathrm{HI}$ pada fungia, $C$. vaugani, yang mungkin ini digunakan sebagai alat pertahanan diri melawan predator.
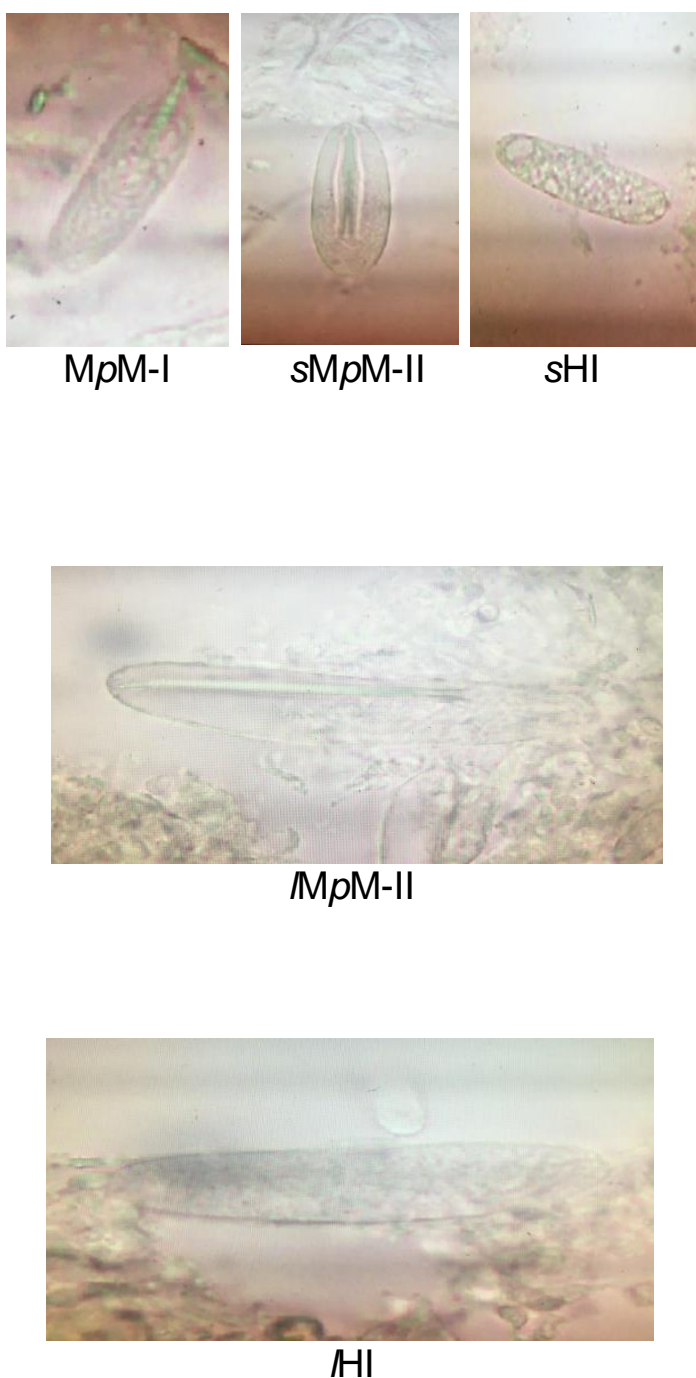

Gambar 4. Tipe-tipe nematosit fungia, $C$. vaugani. 


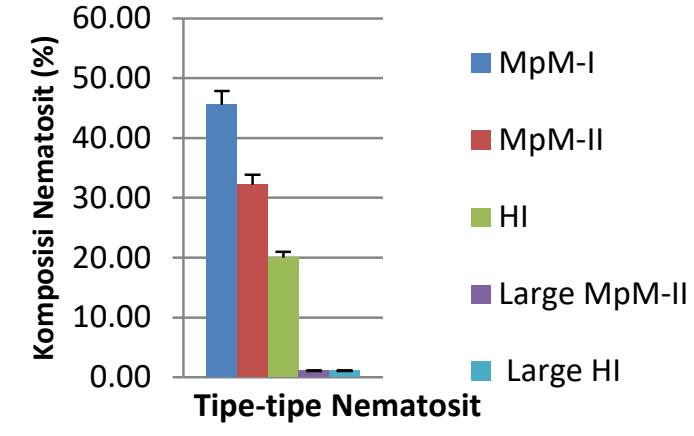

Gambar 5. Komposisi tipe-tipe nematosit dari fungia, C. vaugani

\section{KESIMPULAN DAN SARAN}

\section{Kesimpulan}

Kesimpulan dari penelitian ini bahwa komposisi nematosit karang fungia, $C$. vaugani, yaitu $\mathrm{MpM}-\mathrm{I}$ sebesar 40,00 \%; sMpM-II 31,11\%; sHI 24,44\%; MpM-II 2,22 \% dan $\mathrm{HI}$ 2,22 \%.

\section{Saran}

Penelitian selanjutnya disarankan untuk meneliti lebih lanjut tipe-tipe dan dimensi nematosit dari berbagai jenis karang fungia, termasuk $C$. vaugani untuk memahami perbedaan-perbedaan tipe dan dimensi nematositnya.

\section{DAFTAR PUSTAKA}

Fautin, D.G. 2009. Structural Diversity, Systematics, and Evolution of Cnidae. Toxicon 54: 1054-1064. 11 hal.

Gagu, S., S. Darwisito, B. Th. Wagey, A.P. Rumengan, A.B. Rondonuwu, dan C.P. Paruntu. 2019. Dimensi dan komposisi nematosit pada karang scleractinia, Acropora florida dan Acropora divaricata di Pantai Motandoi Selatan Kabupaten Bolaang Mongondow Selatan. Jurnal Pesisir dan Laut Tropis.
Volume 7 Nomor 3 Tahun 2019. Hal. 227-233.

Gofredo S. and N.E. Chadwick-Furman. 2000. Abundance and distribution of mushroom corals (Scleractinia: Fungiidae) on a coral reef at Eilat, Northern Red Sea. Bulletin Of Marine Science 6 (1):241-254.

Hartog J.C. Den. 1997. The marginal tentacles of Rhodactis sanctithomae (Corallimorpharia) and the sweeper tentacles of Monstrastrea cavernos (Scleractinia) their cnidom and possible function. Proc. $3^{\text {rd }}$ Int. Coral Reef Symp. 1 : 463-469.

Hoeksema, B.W. 1989. Taxonomy, phylogeny and biogeography of mushroom corals (Scleractinia: Fungiidae). Zoologische verhandelingen. Leiden 254:1-295.

Hoeksema, B.W. 2012. Distribution patterns of mushroom corals (Scleractinia: Fungiidae) across the Spermonde Shelf, South Sulawesi. The Raffles Bulletin of Zoology 60 (1): 183-212.

Hoeksema B.W and P. Bongaerts. 2016. Mobility and self-righting by a freeliving mushroom coral through pulsed inflation. Marine Biodiversity 46:521-524.

Lang, J. C. 1986. Whatever Works: The Variable Importance of Skeletal and Non-skeletal Character in Scleractinian Taxonomy. Palaeontology. Amer., 54: 18-44.

Mariscal, R. N. 1974. Nematocyst. In Mustacine, L. And H. M. Lenhoff (eds). Colanterates biology: review and new perspective. Academy Press. New York. Hal. 129-178.

Mariscal, R.N. 1984. Cnidaria: Cnidae. In Bereiter-Hahn J, Matoltsy AG, Richards KS (eds) Biology of the Integument, Vol. 1. Invertebrates. Springer, Berlin Heidelberg New York, pp 57-68.

Ostman, C. 2000. A guideline to nematocyst nomenclature and 
classification, and some notes on the systematic value of nematocysts. Sci. Mar., 64 (Supl. 1): 31-46.

Paruntu, C.P. 1996. Studies on cnidae of scleractinian corals: Developmental changes in cnida composition and spatial distribution of cnidae along mesenterial filaments. Master thesis. University of Ryukyus Okinawa Japan. Hal. 158 dan 1-36.

Paruntu, C.P., K. Hidaka dan M. Hidaka. 2000. Developmental Changes in Cnidae Composition of the Coral Pocillopora damicornis. Galaxea, JCRS. Japan. 2 : 23-28.

Paruntu, C.P., H. Rifai dan J.D. Kusen. 2013. Nematosit dari Tiga Spesies Karang Scleractinia, Genus Pocillopora (Nematocysts of the three Scleractinian Corals of Genus llopora). Jurnal Perikanan dan Kelautan Tropis. Vol. IX, No. 2. Hal. 60-64.

Paruntu, C.P. dan N. Souw. 2014. Morfologi Nematosit dari Dua Spesies Karang Scleractinia (Seriatopora hystrix dan Seriatopora caliendrum). Jurnal LPPM Bidang Sains dan Teknologi, Volume 1 Nomor 1. UNSRAT. MANADO. Hal. 113- 120.

Pires D.O., and F.B. Pitombo. 1992. Cnidae of the Brazillian Mussidae (Cnidaria: Scleractinia) and Their Value in Taxonomy. Bull, of Mar, Sci. 51:(2) 231-244.

Prasetya, I.N.D. 2003. Kajian Jenis dan Kelimpahan Rekrutmen Karang di Pesisir Desa Kalibukbuk, Singaraja, Bali. Universitas Pendidikan Ganesha,Singaraja, Bali.

Schlesinger, Y., T.L. Goulet and Y. Loya. 1998. Reproductive Patterns of Scleractinian Corals in the Northern Red Sea. Mar biol 132: 691-701.
Suharsono. 2008. Jenis-Jenis Karang Di Indonesia. COREMAP-Program LIPI. Jakarta. Hal. 1-297.

Veron, J.E.N. 1986. Corals of Australia and The Indo Pasific, Angus and Robertson Sydney, 644 pp.

Watson G.M., and R.L. Wood. 1988. Colloqioum on Terminology. Hal. 2123. In: Hessinger, D.A. and H.M. Lenhoff (eds). The Biology of Nematocyst, Academic Press Inc. San Diego.

Yue Y., W. Xue, H. Yu, R. Li, P. Li. 2020. Updated descriptions of the nematocysts of the scyphozoan jellyfish Cyanea nozakii Kishinouye, 1891 (Cnidaria, Scyphozoa). Toxicon, Volume 187, November 2020, Pages 271-27 